\title{
The Family Room
}

A place to sleep. For most of us, it is a given in our lives, along with a roof over our heads and our own front door to close. But ever since the beginnings of the European colonization of North America-Jamestown in 1607 , and the Mayflower pilgrims' Plymouth Colony in 1620 - communities on these shores have had to deal with those among them who did not have a place to sleep, people who could not provide for themselves or their children and had no one to give them shelter.

Despite the fact that the New World offered any able-bodied person an abundance of game, seafood, and fertile soil, life was not easy. Disease, war, and accident were constantly thinning the ranks of the colonists, leaving their families to fend for themselves. A woman could be widowed in the blink of an eye, the loosing of an arrow, or the bite of a mosquito. Widows and children who had depended on a man's hard work could suddenly be left with no support. Women bled to death during childbirth or were cut down by fevers, leaving a man behind to raise the children. For one reason or another some people have 
always found themselves trying to maintain families in the most precarious of conditions.

From the Plymouth Colony until today, public officials have generally, if reluctantly, accepted the idea that they were responsible for the care of the desperately poor among them. Local governments to some degree have always accepted an obligation to care for the poor, particularly indigent families with children.

In the winter of 2002 I was staying at a Dearborn, Michigan, motel, researching a completely different topic, when I began to wonder how that obligation was currently being met. Each morning I would rise in my room and go down the hallway to the lobby for free donuts and coffee. Each morning four small, neatly dressed and groomed kids-two boys, two girls-were standing by the front door waiting for a school bus, peering out, packs on their backs.

One morning curiosity moved me to ask the desk clerk who they were. "Homeless," he answered. "The county sent them."

Their families must have had an unusually nasty run of bad luck, I ventured. No, he said, the local shelter for homeless families was full, and the motel — on the outer reaches of Michigan Avenue-was always home to some of the overflow population, rooms paid for at $\$ 60$ a night by Wayne County. One room to a family. Then he added, "But don't worry. We don't let the kids have any donuts in the morning. Those are only for our paying guests."

In the afternoons the kids ran up and down the hall or kicked a ball from one end to the other. The raw Michigan winter made it too cold to play outside for any length of time, and they had energy to burn. It was hard for me to believe that children in the United States were being raised in motel rooms with nowhere else to play but long, narrow hallways on dirty, threadbare carpeting. I began to read about homeless families. 
While the question of how to relieve families living in desperate poverty has a long history, the present situation is different and perhaps worse than it has ever been. Never before has the number of homeless included so many single women with children. Fifty years ago the word "homeless" signified dysfunctional individuals - mostly men-who drank heavily and slept rough. Now it is more likely to mean a young single mother with small children and a minimum-wage job. In 1980 families with children made up only i percent of the nation's homeless; by 2014 that number was 37 percent of the total. ${ }^{1}$

Naïvely, I was shocked to learn that over the course of 2002 more than a million children were homeless in the richest nation in the world. They were living in motel rooms, in cars, in shelters, or doubled and tripled up, packed into the houses of family or friends, the only constant condition being too many people in too little space. An estimated one in every ten of these homeless children lived in a motel, and their families usually included a single parent who could not get enough rent and deposit together at the same time for an apartment, but who was able to scrape by week to week paying for a room. Many of these single parents held minimum-wage jobs. A whole family would live in that room-brothers, sisters, and usually just a mother, though occasionally a man was around too. Furnishings included a microwave, two double beds, a bureau, and a big motel television.

Over the years that have passed since I was in Dearborn, the number of homeless families in the United States has skyrocketed. In 2006 up to I.6 million children were homeless at some time during the year, and by 2014 the number had risen to 2.5 million. ${ }^{2}$ In 2013 twenty million people were living in deep poverty with incomes less than half of the official poverty rate; this 
was almost three times the number who were in such desperate straits in $1976 .^{3}$

The growing gap between the haves and the have-nots has created a huge pool of extremely poor families unmatched since the Great Depression, a vast floodtide of people adrift with nothing to hold on to. They spend long days and nights just getting by, trying to make it through another week without spending money on anything but food and shelter while putting off going to the dentist, or the doctor, or getting the car repaired. Although they are frequently without resources, they must deal with the same problems as the rest of us: illness, debt, substance abuse, sons and daughters in trouble, and the other misfortunes that nip at our heels as we try to get through our days.

This kind of deep family poverty is happening not in isolated pockets across the country but in cities, counties, and states from one end of the nation to the other. Somewhere in our home state, in every state, children are growing up in motel rooms; others are living in cars. That they are below our communal radar is generally okay with their parents: to draw attention can bring trouble. These are not mentally ill people walking the streets wrapped in blankets, or chronically homeless individuals pushing supermarket carts full of all they own. These are mothers trying to keep their children fed, sheltered, and out of the hands of the authorities.

We are apt not to notice them. Life goes on and most of us have all we can do to make it to the other side of any given twenty-four hours without taking note of the homeless families around us. We go through our daily lives with little or no awareness of the rising tide of unanchored, struggling people who are about to go under at any moment and bring their children down with them. A terrible drama is playing out, perhaps only a few 
blocks from where we are living our own complicated, relatively comfortable lives.

It may seem that these people's plights do not directly affect us. Nevertheless, when so many live among us in such hardship, their presence inevitably will have consequences for our communities, eroding the underpinnings of the very society that nurtures us and forms our world. What does it mean if we are thriving when so many people around us are living in misery and having such a hard time getting through each day? What does it mean for them, and what does it mean for us?

It turns out that the question of how to relieve the poorest among us has bedeviled public officials and policy makers for centuries. The biblical declaration that the poor will always be with us has held true throughout our nation's history. Over the centuries only a limited number of options have been found to deal with these families: some type of direct material support to keep them housed and fed; institutionalization in an almshouse or shelter; or placing the children somewhere outside the biological family, either in another home or in an institutional setting such as an orphanage. Variations of each of these solutions have been employed since the first white colonists reached America, and they continue to be applied today, five centuries later, with varying degrees of success.

Two basic schools of thought have always existed. Today these schools often are referred to by social scientists as "structural" and "individual." The former holds that the root cause of a family's extreme poverty is likely to rest with social context: little or no available employment; a lack of education; a dysfunctional family; no access to social services; an exorbitantly high rental market.

The second school assigns the blame for a family's desperate circumstances to some personal failure by the head of the family, 
some vice or weakness of character, an inability to get along in the world that is a person's own fault but for which the family must bear the burden. Poverty is the price to be paid for a life frittered away in substance abuse, promiscuity, or laziness.

In 1897 no less a figure than a past director of the United States Census, Francis Walker, wrote: "Pauperism is, in truth, largely voluntary, to the full degree in which anything can be said to be voluntary in a world of causation - a matter, if not of definite and conscious choice, then of appetites and aptitudes indulged or submitted to from inherent baseness or cowardice or moral weakness. Those who are paupers are so far more from character than from condition. They have the pauper taint; they bear the pauper brand."4

Today as ever, opinions about poverty are closely linked to political affiliation and class. A 2014 poll found that nearly 60 percent of Republicans believe poverty is the result of decisions individuals have taken, compared with only 24 percent of Democrats. ${ }^{5}$ The belief that the poor are primarily responsible for their own plights mitigates, if not annuls, the public responsibility to provide decent room and board to those who cannot provide it for themselves. A substantial segment of our society still holds that to provide more than the barest of assistance to homeless families is to encourage them in shiftlessness and discourage them from bettering themselves.

As politicians, bureaucrats, social service workers, and policy makers spend years, even decades, debating whether and how to help these families, the homeless children in them grow up to adulthood and are incorporated into society. They move among us, many of them scarred, scared, and emotionally stunted for life, growing into parents who will raise yet another generation of extremely poor children. Some few of these children, through 
hard work, focus, and good luck, will grow up to pull themselves out of poverty, but most will never have an opportunity to do so. Various studies are commissioned; ten-year plans are elaborated to end family homelessness; municipal committees are formed to implement the plans. All the while, the gap continues to grow between rich and poor, with more and more people sliding toward the bottom, taking their families with them.

I for one did not have any idea that so many children were adrift around me, and the more miles I logged traveling within this invisible nation, the more I was astonished by their numbers. What also became clear as I spoke with homeless parents, interviewed social service providers, and read histories of family poverty in the United States was that today we have the capacity to eradicate this twenty-first-century plague of family homelessness; we know how to do it; we need only commit to doing so. Hopefully, the following report about the past, present, and future of the invisible nation will encourage that commitment. 
